\title{
The effect of captivity on the skin microbial symbionts in three Atelopus species from the lowlands of Colombia and Ecuador
}

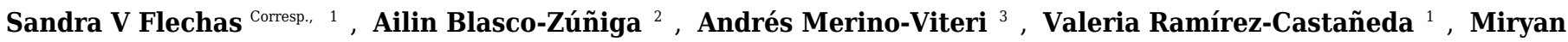
Rivera $^{2}$, Adolfo Amézquita ${ }^{1}$

1 Department of Biological Sciences, Universidad de los Andes, Bogotá, Colombia

2 Laboratorio de Investigación en Citogenética y Biomoléculas de Anfibios (LICBA), Centro de Investigación para la Salud en América Latina (CISeAL), Pontificia Universidad Católica del Ecuador, Pontificia Universidad Católica del Ecuador, Quito, Ecuador

3 Museo de Zoología (QCAZ), Escuela de Ciencias Biológicas, Pontificia Universidad Católica del Ecuador, Quito, Ecuador

Corresponding Author: Sandra V Flechas

Email address: vickyflechas@gmail.com

Many amphibian species are at risk of extinction in their natural habitats due to the presence of the fungal pathogen Batrachochytrium dendrobatidis $(B d)$. For the most highly endangered species, captive assurance colonies have been established as an emergency measure to avoid extinction. Experimental research has suggested that symbiotic microorganisms in the skin of amphibians play a key role against $B d$. While previous studies have addressed the effects of captivity on the cutaneous bacterial community, it remains poorly studied whether and how captive conditions affect the proportion of beneficial bacteria or their anti-Bd performance on amphibian hosts. In this study we sampled three amphibian species of the highly threatened genus, Atelopus, that remain in the wild but are also part of ex situ breeding programs in Colombia and Ecuador. Our goals were to (1) estimate the diversity of culturable bacterial assemblages in these three species of Atelopus, (2) describe the effect of captivity on the composition of skin microbiota, and (3) examine how captivity affects the bacterial ability to inhibit $B d$ growth. Using challenge assays we tested each bacterial isolate against $B d$, and through sequencing of the 16S rRNA gene, we identified species from thirteen genera of bacteria that inhibited $B d$ growth. Surprisingly, we did not detect a reduction in skin bacteria diversity in captive frogs. Moreover, we found that frogs in captivity still harbor bacteria with anti-Bd activity. Although the scope of our study is limited to a few species and to the culturable portion of the bacterial community, our results indicate that captive programs do not necessarily change bacterial communities of the toad skins in a way that impedes the control of $B d$ in case of an eventual reintroduction. 
1 The effect of captivity on the skin microbial symbionts in three Atelopus species from the 2 lowlands of Colombia and Ecuador

3

4 Sandra V. Flechas ${ }^{1}$, Ailin Blasco-Zúñiga ${ }^{2}$, Andrés Merino-Viteri $^{3}$, Valeria Ramírez-Castañeda ${ }^{1}$, 5 Miryan Rivera ${ }^{2} \&$ Adolfo Amézquita ${ }^{1}$

6

$7 \quad{ }^{1}$ Department of Biological Sciences, Universidad de los Andes, Bogotá, AA 4976, Colombia

$8{ }^{2}$ Laboratorio de Investigación en Citogenética y Biomoléculas de Anfibios (LICBA), Centro de

9 Investigación para la Salud en América Latina (CISeAL), Pontificia Universidad Católica del

10 Ecuador, Quito, Ecuador

$11{ }^{3}$ Museo de Zoología (QCAZ), Escuela de Ciencias Biológicas, Pontificia Universidad Católica

12 del Ecuador, Quito, Ecuador

13

14

15 Corresponding author:

16 Sandra V. Flechas $^{1}$

17

18 Email address: vickyflechas@gmail.com 


\section{Abstract}

21

22 Many amphibian species are at risk of extinction in their natural habitats due to the presence of

23 the fungal pathogen Batrachochytrium dendrobatidis $(B d)$. For the most highly endangered

24 species, captive assurance colonies have been established as an emergency measure to avoid

25 extinction. Experimental research has suggested that symbiotic microorganisms in the skin of

26 amphibians play a key role against $B d$. While previous studies have addressed the effects of

27 captivity on the cutaneous bacterial community, it remains poorly studied whether and how

28 captive conditions affect the proportion of beneficial bacteria or their anti- $B d$ performance on

29 amphibian hosts. In this study we sampled three amphibian species of the highly threatened

30 genus, Atelopus, that remain in the wild but are also part of ex situ breeding programs in

31 Colombia and Ecuador. Our goals were to (1) estimate the diversity of culturable bacterial

32 assemblages in these three species of Atelopus, (2) describe the effect of captivity on the

composition of skin microbiota, and (3) examine how captivity affects the bacterial ability to

inhibit $B d$ growth. Using challenge assays we tested each bacterial isolate against $B d$, and

through sequencing of the 16S rRNA gene, we identified species from thirteen genera of bacteria

that inhibited $B d$ growth. Surprisingly, we did not detect a reduction in skin bacteria diversity in

captive frogs. Moreover, we found that frogs in captivity still harbor bacteria with anti- $B d$

activity. Although the scope of our study is limited to a few species and to the culturable portion

of the bacterial community, our results indicate that captive programs do not necessarily change eventual reintroduction. 


\section{Introduction}

45 Global amphibian declines have been attributed to a variety of factors including habitat 46 destruction, contamination, UV-B radiation, climate change, overexploitation, and infectious 47 diseases (Alford \& Richards, 1999; Collins \& Crump, 2009; Heard et al., 2013). Diseases caused 48 by microparasites have been linked to massive mortality events and extinctions, and the 49 causative agents can be viral, bacterial, or caused by protists and fungi (Latney \& Klaphake, 50 2013; Chambouvet et al., 2015). Emerging diseases caused by fungi have become more 51 problematic and the impact on the affected groups are much more alarming (Wake and 52 Vredenburg, 2008; Fisher et al., 2012). Batrachochytrium dendrobatidis (Bd) (Longcore, Pessier 53 \& Nichols, 1999), and B. salamandrivorans (Bsal) (Martel et al., 2013) are highly pathogenic 54 fungi, recognized as the etiological agents of the amphibian infectious disease known as 55 chytridiomycosis. Bsal has been detected only in urodels (salamanders and newts) (Martel et al., $562013 ; 2014)$, while $B d$ is considered a generalist pathogen found in a wide variety of amphibian 57 species across the three orders (i.e., Anura, Urodela and Gymnophiona). $B d$ has been detected in 58 at least 520 amphibian species in 56 countries (Berger et al., 2016) causing population declines 59 in at least 200 species across five continents (Skerratt et al., 2007; Fisher, Garner \& Walker, 60 2009).

62 Conservation strategies focused on ameliorating the lethal effects of the fungal pathogen have 63 been mainly restricted to establishing disease-free ex situ colonies, with the aim of ensuring the 64 survival of susceptible species (Becker et al., 2014; Tapley et al., 2015). Captive programs are a 65 short-term intervention to prevent extinction where the final goal is to reintroduce the animals to 
66 their native habitat (Mendelson et al., 2006). Although, a strategy that ensures host survival

67 despite $B d$ presence is still needed. Meanwhile, ex situ programs may be the best option for many

68 threatened amphibians occurring in complex environments, where in situ strategies are difficult

69 to apply (Bosch et al., 2015). The conditions under which amphibians are maintained in captivity

70 may disturb their associated symbiotic microbes (Kueneman et al., 2016; Loudon et al. 2014),

71 which would affect health status (Li et al., 2008; Becker et al., 2015) and survival rates if

72 released into the wild (Redford et al., 2012; Michaels, Downie \& Campbell-Palmer, 2014b).

74 Cutaneous microbes can inhibit or delay the growth of $B d$ (Harris et al., 2006; 2009; Woodhams

75 et al., 2007), and therapies where beneficial microbes are augmented in the host skin have been

76 considered as an option to treat $B d$-susceptible species in situ (Woodhams et al., 2011; Bletz et

77 al., 2013; Woodhams et al., 2016). However, new approaches should take into account the

78 complex interactions among the host, its symbiotic bacteria and the fungal pathogen, without

79 neglecting the role of the environmental context on these interactions (McKenzie et al., 2012;

80 Kueneman et al., 2014; Bosch et al., 2015). Captivity imposes a different environment that might

81 affect the microbial composition, and thus, the response of the host to the pathogen. Various

82 studies have suggested that skin associated microbes of individuals in captivity differ from those

83 in the wild (Becker et al., 2014, Kueneman et al., 2016, Sabino-Pinto et al., 2016). In the case of

84 the red-eyed tree frog (Agalychnis callidryas), community composition, species richness, and

85 abundance of bacterial groups seem to be influenced mainly by the availability of carotenoids in

86 their diet (Antwis et al., 2014), and by the cover provided in the enclosures (Michaels, Antwis \&

87 Preziosi, 2014a). However, other factors including humidity, temperature, $\mathrm{pH}$ and disinfection

88 methods affect the presence of certain bacterial species and could facilitate or impede 
89 colonization and establishment in the host skin (Mendoza et al., 2012). Some studies have

90 demonstrated that OTU (Operational Taxonomic Units) richness and phylogenetic diversity are

91 significantly higher in captive animals (i.e., in Atelopus zeteki, Becker et al., 2014), while other

92 studies find the opposite, where wild animals harbor a higher bacterial diversity (i.e. Cynops

93 pyrrhogaster, Sabino-Pinto et al., 2016 and, Anaxyrus boreas, Kueneman et al., 2016).

94

95 Although changes in the bacterial assemblage composition due to captivity seem to vary

96 depending on the species, understanding how changes in the bacterial community structure affect

97 the host response to $B d$ infection may be key to successful ex situ programs. For example,

98 Becker et al. (2015) showed that survival rates after exposure to $B d$ seem to be associated with

99 the initial composition of the skin bacterial community, so different initial communities result in

100 different outcomes for the host. Even though scientists have provided important insights on how

101 different factors affect microbial assemblages in captive conditions (Antwis et al., 2014;

102 Michaels, Antwis \& Preziosi, 2014a; Michaels, Downie \& Campbell-Palmer, 2014b), additional

103 research is required to determine the impact of captivity on the proportion of bacteria with anti-

$104 B d$ properties for specific amphibian species. Knowing how captive conditions affect the

105 proportion and performance of bacteria with antifungal capacities will allow us to more

106 accurately predict the fate of species considered for reintroduction into the wild.

107

108 Harlequin toads from the genus Atelopus are considered one of the most threatened groups of

109 amphibians worldwide, with at least $71 \%$ of the species listed as critically endangered according

110 to the IUCN (2016). Although many species have been declining, some species from the

111 lowlands still persist in their natural habitats (Flechas, Vredenburg \& Amézquita, 2015). Other 
112 species, such as A. elegans from Ecuador, has only been found in one of its historical collection

113 localities. Given the crisis of wild amphibian populations and the highly susceptibility of

114 Atelopus to the fungal disease, conservation actions have been focused on keeping assurance

115 colonies in order to protect these species. Conservation initiatives are committed to protecting

116 those species facing the highest risk of extinction, and have included at least 15 species of the

117 genus Atelopus in rescue programs (http://progress.amphibianark.org/model-programs). In this

118 study, we evaluated the effect of ex situ conditions on bacteria with anti- $B d$ activity. To

119 accomplish this, we performed antagonism assays to determine which bacterial species can

120 inhibit $B d$ growth. Then we compared the activity between bacteria isolated from individuals in

121 the wild with those maintained in captivity. We use culture-dependent methods to compare the

122 skin bacterial community in three Atelopus species that persist in the wild but are also part of an

123 ex situ breeding program. Our main goal was to evaluate the effect of captivity on the

124 composition of the skin microbial community, focusing mainly in those that exhibit anti-Bd

125 properties. Since captive environments have been described as less heterogeneous and less

126 diverse compared with natural habitats, we hypothesized that animals in the wild would support

127 a more diverse bacterial community and therefore a higher capacity to inhibit $B d$ growth,

128 increasing chances of host survival.

129

130 Materials \& Methods

131

132 Research permits to conduct this study were provided by the Colombian National Parks

133 Authority, the Ministerio de Ambiente de Colombia, and the Ministerio del Ambiente Ecuador 
134 (MAE) under permits DTSO 019-09, DTSO 001-09, N 10-07032012, 001-11 IC-FAU-

135 DNB/MA and 11-2012-FAU-DPAP-MA.

136

137 Study species

138 We studied three Atelopus species from the lowlands, two occurring in the Pacific coastal forests

139 of Colombia and one in Ecuador (Fig. 1). We took skin bacterial samples of A. spurrelli, in the

140 municipality of Arusí $\left(5.57^{\circ} \mathrm{N}, 77.50^{\circ} \mathrm{W} ; 90 \mathrm{~m}\right), A$. aff. limosus, a species occurring near

141 Capurganá $\left(8.60^{\circ} \mathrm{N}, 77.33^{\circ} \mathrm{W} ; 150 \mathrm{~m}\right)$ near the border between Colombia and Panama, and $A$.

142 elegans from the Esmeraldas Province in northwestern Ecuador $\left(1.04^{\circ} \mathrm{N}, 78.62^{\circ} \mathrm{W} ; 265 \mathrm{~m}\right)$. In

143 addition, we took skin swabs from captive $A$. elegans, $A$. aff. limosus and $A$. spurrelli from the ex

144 situ programs in the Cali Zoo (Cali, Colombia) and the "Balsa de los Sapos" Conservation

145 Initiative at the Pontificia Universidad Católica del Ecuador (Quito, Ecuador). Individuals in

146 captivity came from the same populations where wild samples were collected (Table 1).

\section{Ex situ conditions}

149 Atelopus spurrelli and A. aff. limosus were brought to the Cali Zoo facilities and kept isolated

150 during quarantine (60 days). Then individuals were transferred to the enclosures ( $1 \mathrm{~m} \mathrm{x} 0.5 \mathrm{~m} \mathrm{x}$

$1510.5 \mathrm{~m}$ ) built using $6 \mathrm{~mm}$-thick glass. To better simulate natural conditions, we created a $10 \mathrm{~cm}-$

152 depth pool that occupied a fifth of the tank's base. Each terrarium was connected to an external

153 canister filter AE 306 Resun ${ }^{\circledR}$ (flow: 700L/H, power: 12 watts). The filters were placed below

154 each terrarium and connected with $1 / 2$ " tubing. Natural plants were placed in the tank to provide

155 shelter, sleeping sites and visual barriers for the frogs, as well as to maintain high humidity, good

156 water quality and low levels of nitrogenous waste. Bromeliads, aroids, mosses, orchids and 
157 calatheas were preferred because they tolerate high humidity levels. All individuals were fed five

158 times a week with domestic crickets and fruit flies enriched with vitamin-mineral supplements.

159 Because our study species occur in the lowlands of Colombia, we kept air temperature within

160 enclosures between $24-30{ }^{\circ} \mathrm{C}$ and water temperature at $20.5-22{ }^{\circ} \mathrm{C}$.

161

162 Individuals of $A$. elegans at "Balsa de los Sapos" Conservation Initiative were maintained

163 isolated in independent containers during quarantine (60 days). Afterward, toads were transferred

164 to plastic enclosures $(30 \mathrm{~cm} \times 20 \mathrm{~cm}$ x $20 \mathrm{~cm})$ in which they were kept individually. Each

165 terrarium contained natural plants, leaf litter, and a coconut bark to provide shelter and sleeping

166 sites for the toads. Each container had $3 \mathrm{~cm}$ of water under false floor to maintain high levels of

167 relative humidity. Clean water simulating artificial rain fell four times a day into each container

168 during 5 minutes from a purification system with four filters: polyester film, UV, activated

169 charcoal, and fabric filtration. All toads were fed three times a week with crickets that were

170 sprinkled with vitamins and calcium supplement (Repashi Superfoods). Room temperature

171 ranged between $19.6-22.9^{\circ} \mathrm{C}$.

172

173 Bacterial isolation

174 In order to determine the effect of captive conditions on the composition of cutaneous bacteria, 175 we took skin bacterial samples from captive animals: four A. spurrelli, seven A. aff. limosus and 176 ten individuals of $A$. elegans. All bacterial swab samples from captive animals were collected in

1772012 (Table 1). To compare bacterial communities of captive and wild frogs, samples from wild 178 animals were taken from five individuals of $A$. elegans from Esmeraldas (Ecuador). For wild 
179 individuals of $A$. spurrelli and A. aff. limosus we used the published data from Flechas et al. 180 (2012).

181

182 Individuals were handled with new nitrile gloves and rinsed with $20 \mathrm{~mL}$ of sterile water to 183 remove transient cutaneous microbiota. Each animal was sampled by running a sterile synthetic 184 rayon swab (Medical Wire Equipment MWE 100) on their left, right of their body and ventral 185 surfaces, hindlimbs, and interdigital membranes for a total of 50 strokes. Swabs were stored in 2 $186 \mathrm{~mL}$ cryovials containing $1 \mathrm{~mL}$ DS solution, i.e., a weak salt solution resembling pond water 187 (Boyle et al., 2003). Samples were refrigerated within $24 \mathrm{~h}$ and processed within $48 \mathrm{~h}$ after 188 189 sampling. To isolate pure colonies, we followed the protocol described previously by Flechas et al. (2012). Each isolate was cryopreserved in nutritive broth with $30 \%$ glycerol at $-80^{\circ} \mathrm{C}$.

\section{Growth inhibition assays}

192 To determine the ability of each isolate to inhibit $B d$ growth we performed antagonism assays as 193 previously published (Harris et al., 2006; Lam et al., 2010; Flechas et al., 2012). Assays were 194 conducted using two $B d$ strains: JEL423 (provided by J. E. Longcore, University of Maine, 195 Orono, USA) and EV001 (Flechas et al., 2013). Bacterial isolates from captive animals of the 196 three Atelopus species and from wild A. elegans were challenged against both $B d$ strains in 197 duplicate. Bacterial strains isolated from wild Colombian Atelopus were only tested against the 198 strain JEL 423 since the Colombian strain was not available before 2012. Query bacteria that 199 produced a clear halo were considered as inhibitory (see Fig 1 in Flechas et al., 2012). Isolates 200 that showed signs of growth inhibition were photographed under similar resolution and lighting 201 conditions in a dark background in order to estimate antifungal ability. 
203 Sections of approximately $3.0 \mathrm{~cm} \mathrm{x} 1.75 \mathrm{~cm}$ were taken from digital images of each culture

204 plate: one section was taken from close to the bacterial growth (query bacteria) and two from 205 sections were only $B d$ was present (control section of the plate). To estimate the antifungal action 206 of bacteria, a graphical approach was developed using programming routines for $\mathrm{R}$ software ( $\mathrm{R}$ 207 Core Team, 2016). The three images were read into R using the function raster of 'raster' 208 package (Hijmans, 2015) and then a frequency table was created based on the color present in 209 each pixel using the function freq of the same package. We generated a continuous color scale 210 ranging from 0 (white - representing only presence of $B d$ ) to 255 (black - representing complete

211 absence of $B d$ ). To ensure these extreme values were present in the picture, two circles of equal 212 dimensions (one of each color) were manually added to each image.

214 Because $B d$ does not grow uniformly over the plate's surface, two control assessments were 215 employed: a) We obtained kernel density estimates for each control picture and the average of 216 the modal color value from each picture was used in all posterior analyses. For this step, we used 217 the function density from the 'stats' package in R (R Core Team, 2016) with its default 218 arguments, and, b) the frequency tables of each control picture were averaged by color, and then 219 the color value corresponding to the mode of the kernel density estimates was used as control. 220 These two control values were compared to the modal color value of the picture showing the

221 bacterial effect on $B d$ growth. We assumed that lower experimental values than the control imply

$222 B d$ inhibition (darker background in picture), and no differences between control and

223 experimental values imply no antifungal effect (S1). 


\section{Identification of bacterial isolates}

226 DNA from pure cultures, including inhibitory and non-inhibitory strains were extracted as

227 follows: one colony of each morphotype was re-suspended in $10 \mathrm{~mL}$ of pure water HPLC grade 228 in a $0.2 \mathrm{~mL}$ PCR tube and boiled for $7 \mathrm{~min}$ at $95^{\circ} \mathrm{C}$. PCR amplifications were performed using 229 universal primers 27F and 1492R (Lane, 1991) and the following parameters: an initial 230 denaturation of $3 \mathrm{~min}$ at $95^{\circ} \mathrm{C}$, followed by 35 cycles of $45 \mathrm{~s}$ at $95^{\circ} \mathrm{C}, 45 \mathrm{~s}$ at $52{ }^{\circ} \mathrm{C}$ and $90 \mathrm{~s}$ at $23172{ }^{\circ} \mathrm{C}$, and a final extension of $7 \mathrm{~min}$ at $72^{\circ} \mathrm{C}$. Each reaction consisted of $0.5 \mu \mathrm{L}$ of each primer $232(1 \mu \mathrm{M}), 3.0 \mu \mathrm{L}$ of doubly distilled DNA-free water, $6 \mu \mathrm{L}$ of GoTaq ${ }^{\circledR}$ Green Master Mix (1X;

233 Promega) and $2 \mu \mathrm{L}$ of the DNA extract. PCR results were checked by electrophoresis in $1 \%$ 234 agarose gels. DNA sequences were cleaned and assembled using Geneious (Drummond et al., 235 2011). 16S rRNA sequences were then identified using BLASTn (Altschul et al., 1990) against 236 the complete GenBank nucleotide database (http://www.ncbi.nlm.hih.gov) and the Greengenes 237 database (http://greengenes.lbl.gov) using default parameters in both cases.

238

\section{Statistical analyses}

240 In order to determine the variable (species or condition) that best explained the composition of 241 the skin-associated bacterial community we used a Canonical Correspondence Analysis - CCA 242 using the function $c c a$ in the 'vegan' package in R (Oksanen, 2015). In addition, to compare 243 bacterial diversity between wild and captive animals, we counted the number of bacterial species

244 in each category (species and condition) and then we performed a chi-square test using the 'stats' 245 package in $\mathrm{R}$ (R Core Team, 2016). In order to determine the effect of captivity on bacterial 246 assemblages, we used a chi-square test to check if there were differences in the proportion of

247 bacterial species with antibacterial properties between conditions (wild vs. captive). Lastly, to 
248 test for differences in the capacity of bacterial species to inhibit $B d$ depending on their origin

249 (wild vs. captive), we performed an ANOVA using the data obtained from the image analysis,

250 after testing for normality and homogeneity of variances using Shapiro-Wilk and Bartlett tests,

251 respectively.

252

253

254 Results

255

256 Isolated bacteria from wild and captive individuals

257 Based on morphological characteristics, a total of 153 bacterial morphotypes were isolated from

258 captive individuals: 70 from A. elegans, 62 from $A$. aff. limosus, and 21 from $A$. spurrelli. We

259 recovered 40 morphotypes from wild A. elegans. Fifteen (21\%) bacterial morphotypes from

260 captive and $11(27 \%)$ from wild individuals of $A$. elegans inhibited $B d$ growth in the antagonism 261 assays. For captive $A$. aff. limosus and $A$. spurrelli, 29 of 62 and six of 21 morphotypes inhibited

$262 B d$ growth, respectively (Table 2). Since identification of bacteria based only on morphology is

263 not completely reliable, we sequenced the 16S rRNA gene for all the isolated morphotypes.

264 From 193 culturable morphotypes, we were able to identified bacteria representing 74 OTUs

265 belonging to 37 genera. Through antagonism assays we found 28 OTUs (38\%) in 13 genera

266 showed some degree of anti- $B d$ activity. To define bacterial species we used a cut of $97 \%$

267 similarity. Sequences are available in GenBank with the following accession numbers:

268 KY910042-KY9110115 and KY938077-KY938172.

269

270 Effect of captivity on the composition of skin bacterial community 
271 Although captive and wild individuals from the same host species harbor cutaneous bacteria

272 belonging to the same genera (Fig. 2), we found little overlap in bacterial species diversity

273 between conditions (CCA: $\chi_{\mathrm{df}=1}^{2}=0.408, \mathrm{~F}=1.23, P=0.02$ ) (Table 3, Fig. 3). We did not find

274 evidence for reduction in the number of bacterial species between wild and captive animals

$275\left(\chi_{\mathrm{df}=2}^{2}=3.6551, P=0.1608\right.$, Fig. 4). Antagonism experiments revealed that animals in the wild

276 and individuals kept in ex situ facilities harbor in their skin bacteria with antifungal capacities.

277 Differences in the proportion of bacteria with antifungal abilities between captive (22/64) and

278 wild individuals (18/53) were not significant (Fisher exact test, $P=1$, Odds ratio=1.01, Fig. 4).

279

280 Anti-Bd activity in shared bacterial strains

281 To determine if anti- $B d$ activity changes depending on the origin of the bacteria, we compared

282 the ability to inhibit $B d$ only for those bacterial species that were found in both captive and wild

283 animals. We detected five bacterial species that inhibited $B d$ growth in both conditions including:

284 Acinetobacter sp., Chryseobacterium sp., C. meningosepticum, Pseudomonas putida, and

285 Pseudomonas sp. The inhibition was measured as a reduction of density of $B d$ colonies (based on

286 the presence of darker pixels in the experimental area). Differences in the extent of inhibition

287 between bacteria isolated from wild and captive animals were not detected $(\mathrm{F}=0.503, P=0.73$;

288 Fig. 5). Bacteria inhibit $B d$ growth irrespective of the $B d$ strain used (JEL or EV001, Fisher exact 289 test, $P=0.051$, Odds ratio $=0.385$ ).

290

291

292 Discussion

293 
294 The genus Atelopus is one of the most threatened groups of amphibians worldwide. Although

295 more than $70 \%$ of the species in the genus are listed as critically endangered according to the

296 IUCN (2016), some species have persisted in the wild (Flechas, Vredenburg \& Amézquita, 2015).

297 In other cases, such as $A$. elegans from Ecuador, this species has been recently rediscovered but

298 only in one of the historical localities. Given the high susceptibility of the genus to

299 chytridiomycosis, and the lack of a cure that could allow them to survive in nature, conservation

300 actions have been focused on keeping assurance colonies. In this study, we describe culturable

301 bacterial assemblages for individuals of three Atelopus species that remain in the wild, in

302 apparently healthy conditions, and individuals (from the same species and collection localities)

303 brought into captivity. This study sought to determine the effect of captive conditions on the anti-

$304 B d$ bacterial community in one of the most threatened genera worldwide (La Marca et al., 2005;

305 Mendelson et al., 2006). Our main goal was not only to describe the culturable portion of the

306 bacterial community for each condition, but the effect of captivity on the proportion of beneficial

307 bacteria and their performance as $B d$ inhibitors. Although our results show that captive

308 individuals harbor bacteria with anti- $B d$ properties, further long-term research is key to evaluate

309 the interactions between the skin microbial communities and their amphibian hosts since those

310 can differ from one population to the next even if the bacterial community composition is similar

311 (Rebollar et al., 2016).

313 Several studies have reported changes in the microbial associated communities when animals are

314 moved from the wild to captive environments (Isaacs et al., 2009; Dhanasiri et al., 2011;

315 Wienemann et al., 2011; Nelson et al., 2013). In amphibians, research assessing the effect of

316 captivity on bacterial communities is increasing (Antwis et al., 2014; Becker et al., 2014; 
317 Michaels, Antwis \& Preziosi, 2014a; Kueneman et al., 2016). Through culture-independent and

318 dependent approaches, these studies have demonstrated changes in the skin bacterial community

319 composition due to conditions imposed by captivity. Our results suggest that ex situ conditions,

320 at least for these three Atelopus species, did not reduce the diversity of bacteria or the proportion

321 of anti- $B d$ bacteria, as determined by culture-based assays. Moreover, we found a higher number

322 of culturable bacterial species in captive animals compared to wild individuals. Our findings are

323 consistent with those obtained for other vertebrates including birds and mammals (Xenoulis et al.,

324 2010; Nelson et al., 2013;) where gut microbial diversity was higher in captive animals, and are

325 also consistent with the findings for the Panamanian golden frogs (A. zeteki) where OTU

326 richness and phylogenetic diversity was higher in captive frogs (Becker et al., 2014). We found

327 that species of bacteria belonging to the genera Pseudomonas, Chryseobacterium and

328 Acinetobacter isolated from wild and captive animals inhibited $B d$ in the challenge assays. In a

329 recent study, bacterial isolates from these three groups were also reported as $B d$ inhibitors and

330 they appeared to be widely distributed. The proportion of bacteria that showed anti- $B d$ activity

331 for those genera was 73\% for Pseudomonas, 55\% for Chryseobacterium and $37 \%$ for

332 Acinetobacter (Woodhams et al., 2015).

334 Variations in bacterial communities due to captive conditions have been demonstrated in red-

335 backed salamanders (Plethodon cinereus), where environmental microbes seemed to affect host-

336 microbial diversity and appeared to be important as regulators of the host core community

337 (Loudon et al., 2014). In terms of their associated microbiota, captive environments appear to be

338 less diverse and less heterogeneous than wild habitats, which might imply that host associated

339 bacterial communities for animals in ex situ facilities should be less diverse (Sabino-Pinto et al., 
340 2016). The enclosures where frogs are maintained provide a modified environment that can also

341 vary depending on the zoo or facility. These conditions could facilitate the transmission of new

342 bacteria capable of colonizing the frog skin, as suggested for other animals in captivity (Nelson

343 et al., 2013). We found that culturable bacterial communities from captive animals at the Cali

344 Zoo (A. aff. limosus and A. spurrelli) were not the same but more similar to each other than

345 compared with $A$. elegans. The slight difference between captive $A$. aff. limosus and A. spurrelli

346 (Fig. 2), suggests that a "host" component is also playing a role shaping skin bacterial

347 communities, as suggested previously for Japanese amphibians (Sabino-Pinto et al., 2016).

348 Although the cages used in this study simulated natural conditions, we propose that the observed

349 differences between frogs from both ex situ facilities might be related to the environmental

350 conditions inside the enclosures (i.e., substrate and water sources). Although, there is no solid

351 evidence on which mechanisms are the frogs using to acquire bacteria from the environment, and

352 which are the key factors modeling bacterial assemblages, we suggest that either the environment

353 and host characteristics are modeling bacterial communities in these species of harlequin toads.

355 A cure or mechanism that allows threatened amphibian species to survive chytridiomycosis in 356 their natural habitats is still needed. Although many different disease mitigation strategies have 357 been proposed (Woodhams et al., 2011; Bosch et al., 2015), keeping viable assurance colonies in 358 captivity seems to be the best option for $B d$-susceptible species yet (Gratwicke et al., 2015). The 359 main goal of ex situ programs is to eventually reintroduce animals to their natural habitats.

360 Management in captivity can lead to alterations of the species' microbiota that may reduce 361 survival chances after reintroduction (Redford et al., 2012). In this study, we isolated a similar 362 number of bacterial species with anti- $B d$ activity from captive and wild individuals of three 
363 Atelopus species, suggesting that they might count on their skin bacteria as a potential defense

364 barrier against $B d$. Redford et al. (2012) proposed that more studies are needed to determine

365 changes and alterations in the animals' microbiome in order to increase the success of

366 reintroduction efforts. Here, we presented evidence that although bacterial community structure

367 changed in captivity, the predicted anti- $B d$ function remained intact. In addition, it seems that

368 animals are acquiring new microorganisms that are also providing protection against the fungal

369 pathogen. Our findings suggest that selection acted on bacterial community function (e.g.,

370 antifungal activity and protection) as opposed to selection for specific community structures. We

371 hope this study might be considered when reintroduction plans are proposed as the next step for

372 many species that are now part of ex situ programs.

373

374

375 Acknowledgments

376

377 For assistance in the field we thank D. Velalcázar, A. Barahona, J. Méndez and C. Silva. We 378 would like to thank "Balsa de los Sapos" Conservation Initiative and the Cali Zoo for allowing 379 us to take samples of captive animals. We thank B. Liger for creating the distribution map. We

380 thank A. J. Crawford for helpful comments and suggestions that greatly improved this

381 manuscript. We would like to thank the reviewers for their valuable comments on the 382 manuscript. 
384 Literature cited

385 Alford RA, Richards SJ 1999. Global amphibian declines: A problem in applied ecology. Annual 386 Review of Ecology and Systematics 30:133-165.

387 Altschul SF, Gish W, Miller W, Myers EW, Lipman DJ 1990. Basic local alignment search tool. 388 Journal of Molecular Biology 215:403-410.

389 Antwis RE, Haworth RL, Engelmoer DJP, Ogilvy V, Fidgett AL, Preziosi RF 2014. Ex situ diet

390 influences the bacterial community associated with the skin of red-eyed tree frogs 391 (Agalychnis callidryas). PLoS ONE 9:e85563. DOI:10.1371/journal.pone.0085563

392 Becker MH, Richards-Zawacki CL, Gratwicke B, Belden LK 2014. The effect of captivity on the 393 cutaneous bacterial community of the critically endangered Panamanian golden frog (Atelopus zeteki). Biological Conservation 176:199-206. DOI:10.1016/j.biocon.2014.05.029

395 Becker MH, Walke JB, Cikanek S, Savage AE, Mattheus N, Santiago CN, Minbiole KPC, Harris 396 RN, Belden LK, Gratwicke B 2015. Composition of symbiotic bacteria predicts survival in Panamanian golden frogs infected with a lethal fungus. Proceedings of the Royal Society B: Biological Sciences 282:20142881-20142881. DOI:10.1098/rspb.2014.2881

Berger L, Roberts AA, Voyles J, Longcore JE, Murray KA, Skerratt LF 2016. History and recent progress on chytridiomycosis in amphibians. Fungal Ecology 19:89-99.

DOI:10.1016/j.funeco.2015.09.007

Bletz MC, Loudon AH, Becker MH, Bell SC, Woodhams DC, Minbiole KPC, Harris RN 2013. Mitigating amphibian chytridiomycosis with bioaugmentation: Characteristics of effective 404 probiotics and strategies for their selection and use. Ecology Letters 16:807-820. DOI:10.1111/ele.12099 
407

408

409

410

411

412

413

414

415

416

417

418

419

420

421

422

423

424

425

426

427

428

429

Successful elimination of a lethal wildlife infectious disease in nature. Biology Letters 11:20150874. DOI:10.1098/rsbl.2015.0874

Boyle DG, Hyatt AD, Daszak P, Berger L, Longcore JE, Porter D, Hengstberger SG, Olsen V 2003. Cryo-archiving of Batrachochytrium dendrobatidis and other chytridiomycetes. Diseases of Aquatic Organisms 56:59-64.

Chambouvet A, Gower DJ, Jirků M, Yabsley MJ, Davis AK, Leonard G, Maguire F, DohertyBone TM, Bittencourt-Silva GB, Wilkinson M, Richards TA 2015. Cryptic infection of a broad taxonomic and geographic diversity of tadpoles by Perkinsea protists. Proceedings of the National Academy of Sciences, USA 112:E4743-E4751. DOI:10.1073/pnas.1500163112

Collins JP, Crump ML 2009. Extinction in our Times: Global Amphibian Decline. New York: Oxford University Press.

Dhanasiri AKS, Brunvold L, Brinchmann MF, Korsnes K, Bergh Ø, Kiron V 2011. Changes in the intestinal microbiota of wild atlantic cod Gadus morhua L. upon captive rearing. Microbial Ecology 61:20-30. DOI:10.1007/s00248-010-9673-y

Drummond AJ, Ashton B, Buxton S, Cheung M, Cooper A, Duran C, Field M, Heled J, Kearse M, Markowitz S, Moir R, Stones-Havas S, Sturrock S, Thierer TWA, Wilson A 2011.Geneious v5.4, (accessed October 20, 2014).

Fisher MC, Garner TWJ, Walker SF 2009. Global emergence of Batrachochytrium dendrobatidis and amphibian chytridiomycosis in space, time, and host. Annual Review of Microbiology 63:291-310. DOI:10.1146/annurev.micro.091208.073435

Fisher MC, Henk DA, Briggs CJ, Brownstein JS, Madoff LC, McCraw SL, Gurr SJ 2012. Emerging fungal threats to animal, plant and ecosystem health. Nature 484:186-194. Flechas SV, Sarmiento C, Cárdenas ME, Medina EM, Restrepo S, Amézquita A 2012. Surviving 
430

431

432

433

434

435

436

437

438

439

440

441

442

443

444

445

446

447

448

449

450

451

452

chytridiomycosis: Differential anti-Batrachochytrium dendrobatidis activity in bacterial isolates from three lowland species of Atelopus. PLoS ONE 7:e44832.

DOI:10.1371/journal.pone.0044832

Flechas SV, Medina EM, Crawford AJ, Sarmiento C, Cárdenas ME, Amézquita A, Restrepo S 2013. Characterization of the first Batrachochytrium dendrobatidis isolate from the Colombian Andes, an amphibian biodiversity hotspot. EcoHealth 10:72-76.

DOI:10.1007/s10393-013-0823-9

Flechas SV, Vredenburg VT, Amézquita A 2015. Infection prevalence in three lowland species of harlequin toads from the threatened genus Atelopus. Herpetological Review 46:528-532.

Gratwicke B, Ross H, Batista A, Chaves G, Crawford AJ, Elizondo L, Estrada A, Evans M, Garelle D, Guerrel J, Hertz A, Hughey M, Jaramillo CA, Klocke B, Mandica M, Medina D, Richards-Zawacki CL, Ryan MJ, Sosa Bartuano A, Voyles J, Walker B, Woodhams DC,

Ibáñez R 2015. Evaluating the probability of avoiding disease-related extinctions of Panamanian amphibians through captive breeding programs. Animal Conservation:1-13.

DOI:10.1111/acv.12249

Harris RN, James TY, Lauer A, Simon MA, Patel A 2006. Amphibian pathogen Batrachochytrium dendrobatidis is inhibited by the cutaneous bacteria of amphibian species. EcoHealth 3:53-56. DOI:10.1007/s10393-005-0009-1

Harris RN, Brucker RM, Walke JB, Becker MH, Schwantes CR, Flaherty DC, Lam BA, Woodhams DC, Briggs CJ, Vredenburg VT, Minbiole KPC 2009. Skin microbes on frogs prevent morbidity and mortality caused by a lethal skin fungus. The ISME Journal 3:818824. DOI:10.1038/ismej.2009.27

Heard MJ, Smith KF, Ripp K, Berger M, Chen J, Dittmeier J, Goter M, McGarvey ST, Ryan E 
453

454

455

456

457

458

459

460

461

462

463

464

465

466

467

468

469

470

471

472

473

474

475

2013. Increased threat of disease as species move towards extinction. Conservation Biology 27:1378-1388. DOI:10.1111/cobi.12143

Hijmans, R.J. (2015) Raster: Geographic Data Analysis and Modeling. R Package Version 2.324. http://CRAN.R-project.org/package=raster

Isaacs LT, Kan J, Nguyen L, Videau P, Anderson MA, Wright TL, Hill RT 2009. Comparison of the bacterial communities of wild and captive sponge Clathria prolifera from the Chesapeake Bay. Marine Biotechnology 11:758-770. DOI:10.1007/s10126-009-9192-3

IUCN 2016. IUCN Red List of Threatened Species. Downloaded on 17 July 2016.

Kueneman JG, Parfrey LW, Woodhams DC, Archer HM, Knight R, McKenzie VJ 2014. The amphibian skin-associated microbiome across species, space and life history stages. Molecular Ecology 23:1238-1250.

Kueneman JG, Woodhams DC, Van Treuren W, Archer HM, Knight R, McKenzie VJ 2016. Inhibitory bacteria reduce fungi on early life stages of endangered Colorado boreal toads (Anaxyrus boreas). The ISME Journal 10:934-944.

La Marca E, Lips KR, Lötters S, Puschendorf R, Ibáñez R, Rueda-Almonacid JV, Schulte R, Marty C, Castro F, Manzanilla-Puppo J, García-Pérez JE, Bolaños F, Chaves G, Pounds JA, Toral E, Young BE 2005. Catastrophic population declines and extinctions in neotropical harlequin frogs (Bufonidae: Atelopus). Biotropica 37:190-201. doi:10.1111/j.17447429.2005.00026.x

Lam BA, Walke JB, Vredenburg VT, Harris RN 2010. Proportion of individuals with antiBatrachochytrium dendrobatidis skin bacteria is associated with population persistence in the frog Rana muscosa. Biological Conservation 143:529-531.
DOI:10.1016/j.biocon.2009.11.015 
476 Lane DJ 1991. 16S/23S rRNA sequencing. In: Stackerbrandt, E., Goodfellow M, editors. Nucleic 477 acid techniques in bacterial systematics. New York. Wiley. pp. 115-175.

478 Latney LV, Klaphake E 2013. Selected emerging diseases of amphibia. Veterinary Clinics of 479 North America: Exotic Animal Practice 16:283-301. DOI:10.1016/j.cvex.2013.01.005

480 Li M, Wang B, Zhang M, Rantalainen M, Wang S, Zhou H, Zhang Y, Shen J, Pang X, Zhang M, 481 Wei H, Chen Y, Lu H, Zuo J, Su M, Qiu Y, Jia W, Xiao C, Smith LM, Yang S, Holmes E, 482 Tang H, Zhao G, Nicholson JK, Li L, Zhao L 2008. Symbiotic gut microbes modulate 483 484 485 486 487 488 489 490 491 492 493 494 495 496 human metabolic phenotypes. Proceedings of the National Academy of Sciences, USA 105:2117-2122. DOI:10.1073/pnas.0712038105

Longcore JE, Pessier AP, Nichols DK 1999. Batrachochytrium dendrobatidis gen. et sp. nov., a chytrid pathogenic to amphibians. Mycologia 91:219. DOI:10.2307/3761366

Loudon AH, Woodhams DC, Parfrey LW, Archer H, Knight R, McKenzie VJ, Harris RN 2014. Microbial community dynamics and effect of environmental microbial reservoirs on redbacked salamanders (Plethodon cinereus). The ISME Journal 8:830-840.

McKenzie VJ, Bowers RM, Fierer N, Knight R, Lauber CL 2012. Co-habiting amphibian species harbor unique skin bacterial communities in wild populations. The ISME Journal 6:588-596. DOI:10.1038/ismej.2011.129

Martel A, Sluijs der AS-V, Blooi M, Bert W, Ducatelle R, Fisher MC, Woeltjes A, Bosman W, Chiers K, Bossuyt F, Pasmans F 2013. Batrachochytrium salamandrivorans sp. nov. causes lethal chytridiomycosis in amphibians. Proceedings of the National Academy of Sciences, USA 110:15325-15329.

497 Martel A, Blooi M, Adriaensen C, Van Rooij P, Beukema W, Fisher MC, Farrer RA, Schmidt 498 BR, Tobler U, Goka K, Lips KR, Muletz C, Zamudio KR, Bosch J, Lötters S, Wombwell E, 
499

500

501

502

503

504

505

506

507

508

509

510

511

512

513

514

515

516

517

518

519

520

521

Garner TWJ, Cunningham AA, Sluijs der AS-V, Salvidio S, Ducatelle R, Nishikawa K, Nguyen TT, Kolby JE, Van Bocxlaer I, Bossuyt F, Pasmans F 2014. Recent introduction of a chytrid fungus endangers Western Palearctic salamanders. Science 346:630-631.

Mendelson JRI, Lips KR, Gagliardo RW, Rabb GB, Collins JP, Diffendorfer JE, Daszak P, Ibáñez D R, Zippel KC, Lawson DP, Wright KM, Stuart SN, Gascon C, Silva HRD, Burrowes PA, Joglar RL, Marca EL, Lötters S, Preez LHD, Weldon C, Hyatt A, RodríguezMahecha JV, Hunt S, Robertson H, Lock B, Raxworthy CJEA 2006. Confronting amphibian declines and extinctions. Science 313:48-48. DOI:10.1126/science.1128396

Mendoza GM, Pasteris SE, Ale CE, Otero MC, Bühler MI, Nader-Macías MEF 2012. Cultivable microbiota of Lithobates catesbeianus and advances in the selection of lactic acid bacteria as biological control agents in raniculture. Research in Veterinary Science 93:1160-1167.

Michaels CJ, Antwis RE, Preziosi RF 2014a. Impact of plant cover on fitness and behavioural traits of captive red-eyed tree frogs (Agalychnis callidryas). PLoS ONE 9:e95207.

\section{DOI:10.1371/journal.pone.0095207}

Michaels CJ, Downie JR, Campbell-Palmer R 2014b. The importance of enrichment for advancing amphibian welfare and conservation goals. Amphibian Reptile Conservation $8: 7-23$

Nelson TM, Rogers TL, Carlini AR, Brown MV 2013. Diet and phylogeny shape the gut microbiota of Antarctic seals: a comparison of wild and captive animals. Environmental Microbiology 15:1132-1145. DOI:10.1111/1462-2920.12022.

Oksanen J, Blanchet FG, Kindt R, Legendre P, Minchin PR, O'Hara RB, Simpson GL, Solymos P, Stevens MHH, Wagner H 2015. Community Ecology Package. R package version 2.0-2. http://CRAN.R-project.org/package=vegan 
522 R Development Core Team 2016. R: A language and environment for statistical computing. R

523 Foundation for Statistical Computing, Vienna, Austria. ISBN 3-900051-07-0, URL

$524 \quad$ http://www.R-project.org/.

525 Rebollar EA, Antwis RE, Becker MH, Belden LK, Bletz MC, Brucker RM, Harrison XA,

526 Hughey MC, Kueneman JG, Loudon AH, McKenzie V, Medina D, Minibiole KPC, Rollins-

527 Smith LA, Walke JB, Weiss S, Woodhamns DC, Harris RN 2016. Using “omics” and

528 integrated multi-omics approaches to guide probiotic selection to mitigate chytridiomycosis

529 and other emerging infectious diseases. Frontiers in Microbiology.

530 doi.org/10.3389/fmicb.2016.00068

531 Redford KH, Segre JA, Salafsky N, del Rio CM, McAloose D 2012. Conservation and the

532 microbiome. Conservation Biology 26:195-197. DOI:10.1111/j.1523-1739.2012.01829.x

533 Sabino-Pinto J, Bletz MC, Islam MM, Shimizu N, Bhuju S, Geffers R, Jarek M, Kurabayashi A,

534 Vences M 2016. Composition of the cutaneous bacterial community in Japanese amphibians:

535 Effect of captivity, host species and body region. Microbial Ecology. DOI: 10.1007/s00248-

$536 \quad 016-0797-6$

537 Skerratt LF, Berger L, Speare R, Cashins SD, McDonald KR, Philott AD, Hines HB, Kenyon N

538 2007. Spread of chytridiomycosis has caused the rapid global decline and extinction of frogs.

$539 \quad$ EcoHealth 4:125-134. DOI: 10.1007-s10393-007-0093-5

540 Tapley B, Bradfield KS, Michaels C, Bungard M 2015. Amphibians and conservation breeding

541 programmes: do all threatened amphibians belong on the ark? Biodiversity and Conservation

$542 \quad 24: 2625-2646$. DOI:10.1007/s10531-015-0966-9

543 Wake DB, Vredenburg VT 2008. Are we in the midst of the sixth mass extinction? A view from

544 the world of amphibians. Proceedings of the National Academy of Sciences, USA 
546 doi:10.1038/ismej.2014.77

547 Wienemann T, Schmitt-Wagner D, Meuser K, Segelbacher G, Schink B, Brune A, Berthold P

548 2011. The bacterial microbiota in the ceca of Capercaillie (Tetrao urogallus) differs between

549 wild and captive birds. Systematic and Applied Microbiology 34:542-551.

$550 \quad$ DOI:10.1016/j.syapm.2011.06.003

551 Woodhams DC, Vredenburg VT, Simon MA, Billheimer D, Shakhtour B, Shyr Y, Briggs CJ, 552 Rollins-Smith LA, Harris RN 2007. Symbiotic bacteria contribute to innate immune 553 defenses of the threatened mountain yellow-legged frog, Rana muscosa. Biological 554

555 Woodhams DC, Bosch J, Briggs CJ, Cashins SD, Davis LR, Lauer A, Muths E, Puschendorf R, 556 Schmidt BR, Sheafor B, Voyles J 2011. Mitigating amphibian diseases: Strategies to 557 maintain wild populations and control chytridiomycosis. Frontiers in Zoology 8:8.

$558 \quad$ DOI: $10.1186 / 1742-9994-8-8$

559 Woodhams DC, Alford R, Antwis RE, Archer H, Becker M, Belden L, Bell SC, Bletz M, Daskin 560 JH, Davis L, Flechas SV, Lauer A, Gonzalez A, Harris, RN., Holden W, Hughey M, Ibañez 561 R, Knight R, Kueneman J, Rabemananjara F, Reinert L, Rollins-Smith L, Roman-Rodriguez 562 F, Shaw SD, Walke J, McKenzie V 2015. Antifungal isolates database of amphibian skin563 associated bacteria and function against emerging fungal pathogens. Ecological $564 \quad$ Archives. 96: 595

565 Woodhams DC, Bletz M, Kueneman J, McKenzie VJ 2016. Managing amphibian disease with 566 skin microbiota. Trends in Microbiology 24:161-164. DOI:10.1016/j.tim.2015.12.010 567 Xenoulis PG, Gray PL, Brightsmith D, Palculict B, Hoppes S, Steiner JM, Tizard I, Suchodolski 
568 JS 2010. Molecular characterization of the cloacal microbiota of wild and captive parrots.

569 Veterinary Microbiology 146:320-325. DOI:10.1016/j.vetmic.2010.05.024

570 
Figure 1

Sampling sites

Map showing the localities where bacterial samples were obtained Atelopus aff. limosus (green dot), Atelopus spurrelli (blue triangle) Atelopus elegans (red square). Individuals brought to captivity were collected in the same localities where samples from wild individuals were obtained. The map was created using the profiles provided by GADM.
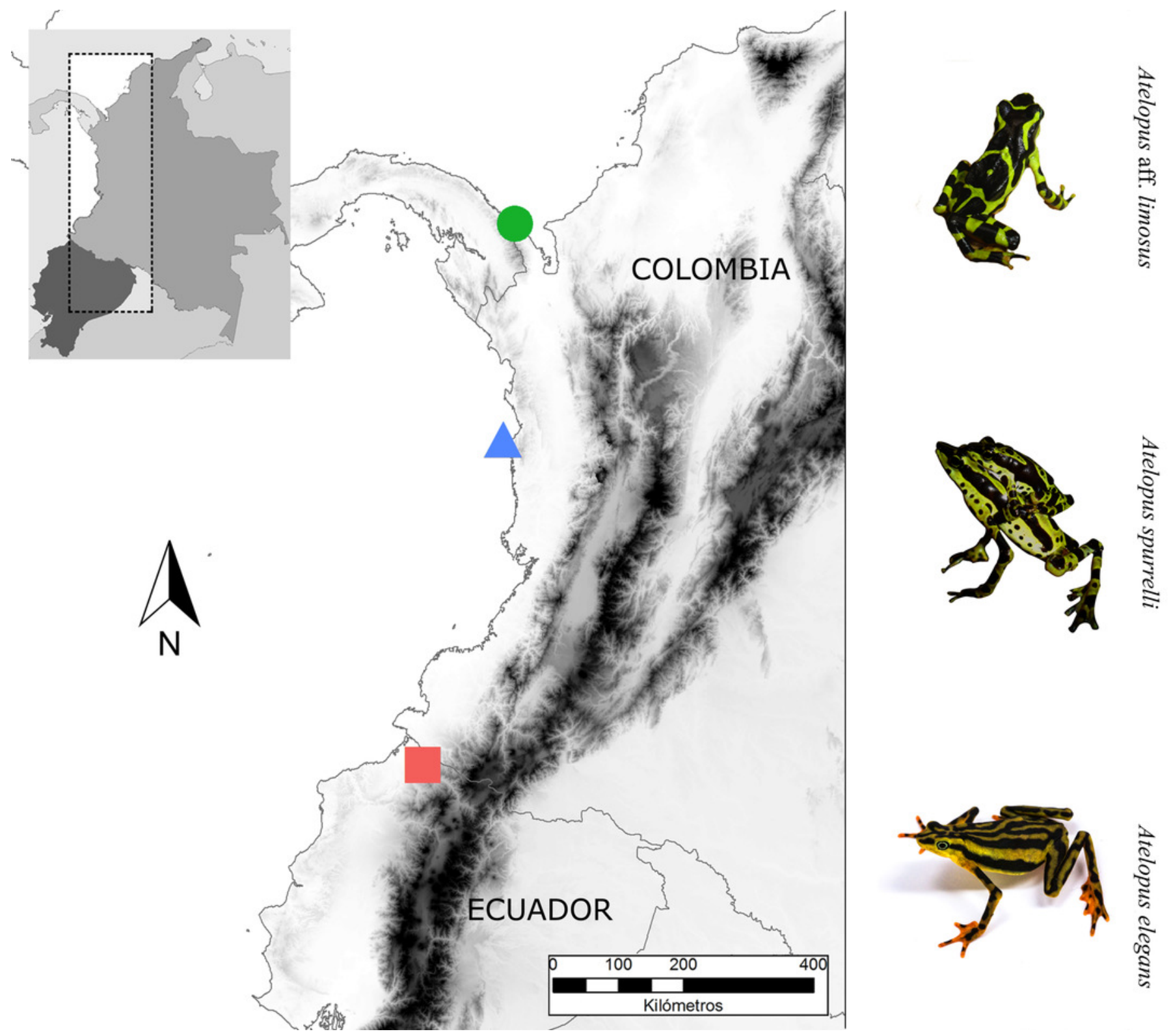
Figure 2

Differences in the relative abundance of culturable bacterial genera isolated from the skin of captive and wild individuals in three species of Atelopus.

Bars are grouped by species and condition. Numbers inside the bars denote the number of toads sampled per category. $\mathrm{C}=$ Captive, $\mathrm{W}=$ Wild.

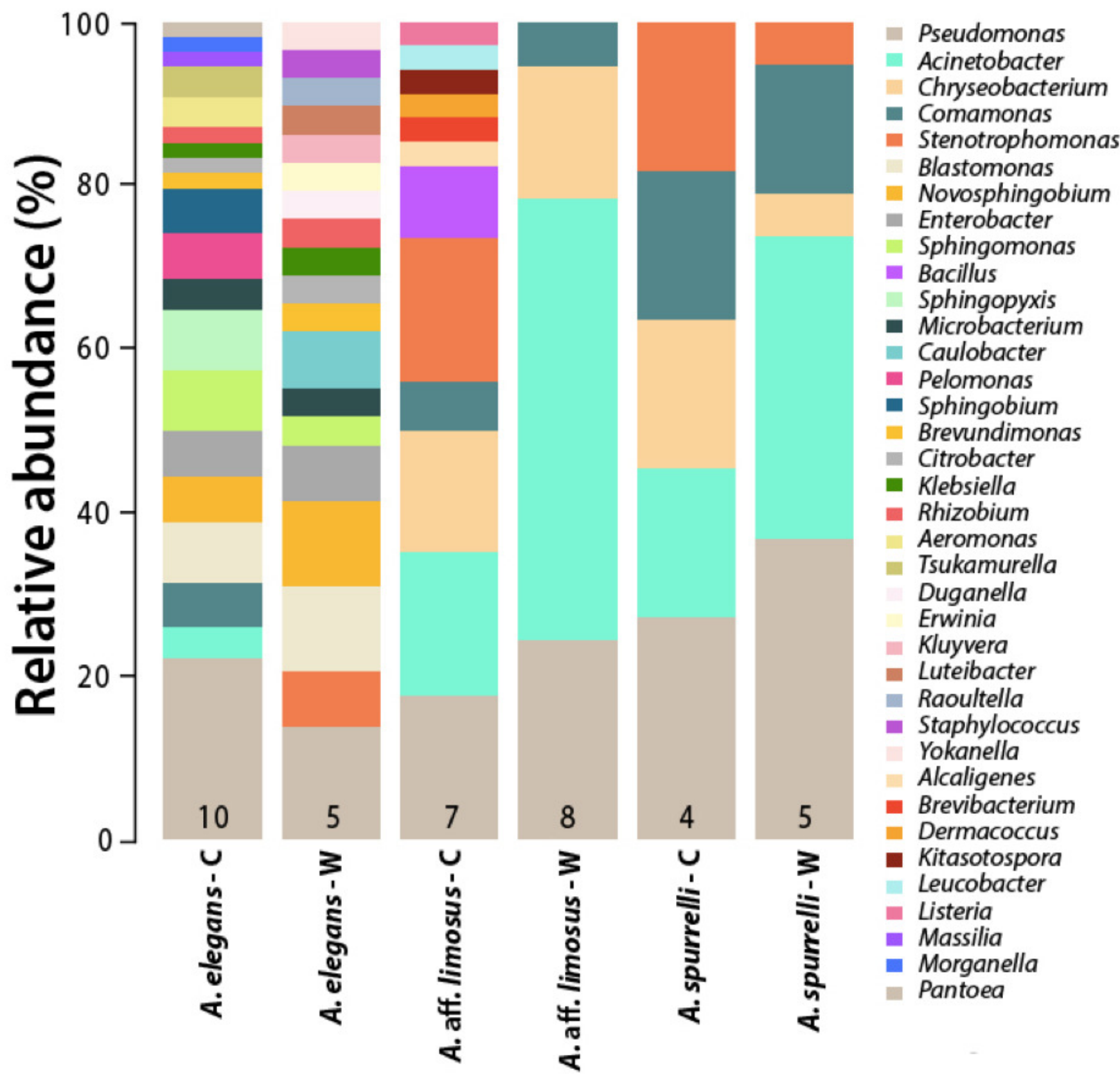


Figure 3

Culturable bacterial communities between captive and wild individuals of Atelopus exhibit little overlap.

Non-metric Multidimensional Scaling (NMDS) ordination of Bray-Curtis distances between microbial communities. Each symbol represents one sampled individual. Ellipses represent 95\% confidence intervals (Dark grey $=$ wild, light grey = captive).

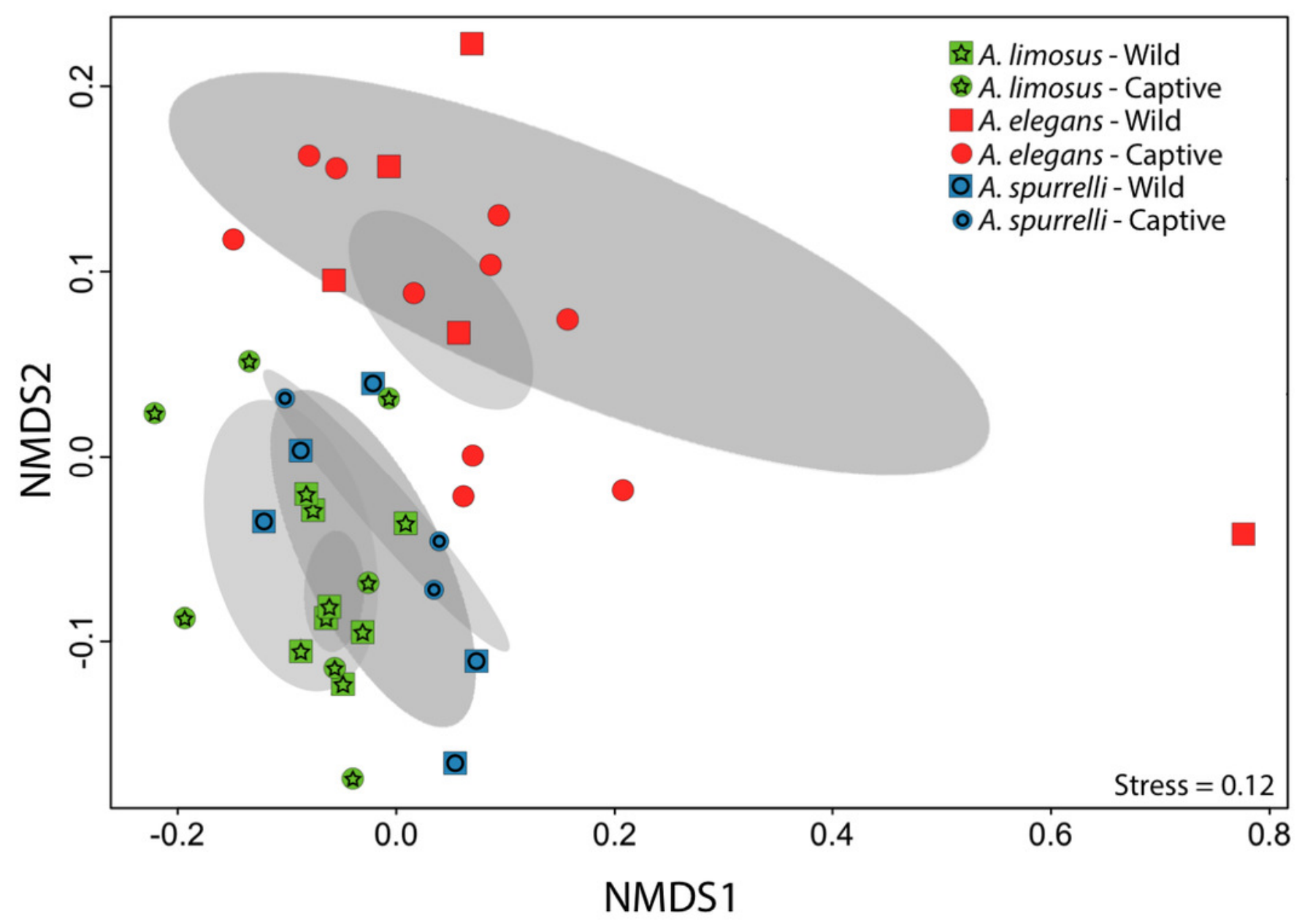




\section{Figure 4}

Atelopus in the wild and in captivity harbor in their skin culturable bacteria with antifungal abilities.

Darker bars show the total number of isolated bacteria in each condition (wild vs. captive). Lighter bars represent the number of bacterial species with anti-Bd activity in each condition (wild vs. captive).

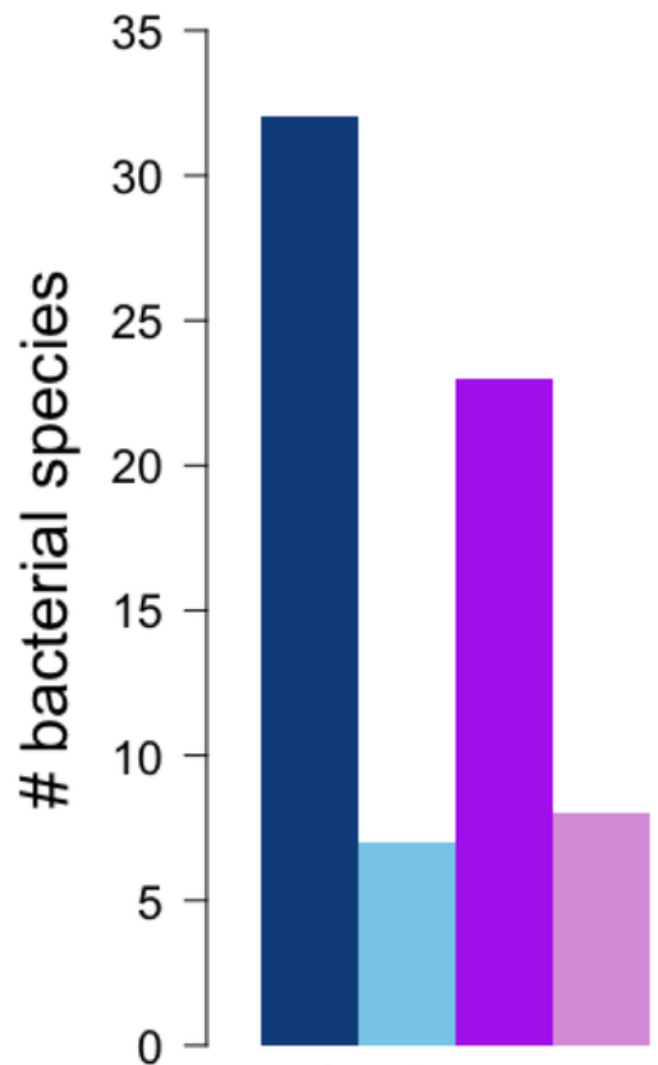

A. elegans

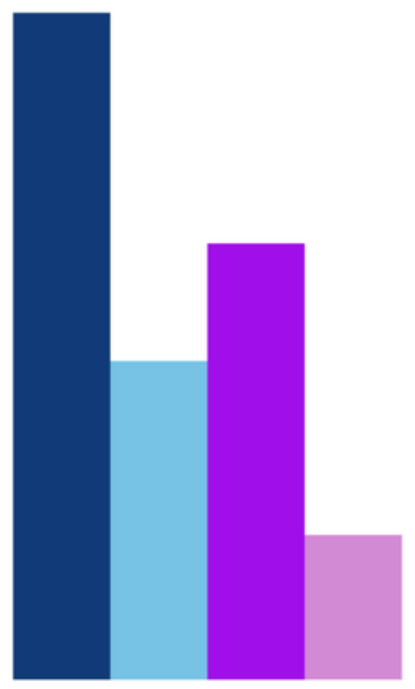

A. aff. limosus
- Captive-All

- Captive-Inhibitory

Wild-All

Wild-Inhibitory

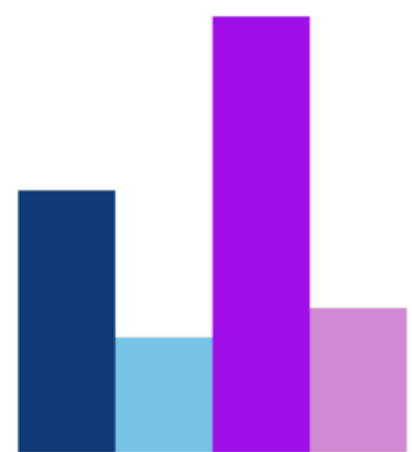

A. spurrelli 
Figure 5

Bacteria isolated from wild and captive animals did not differ in the extent of $B d$ inhibition.

Colored dots were only used for those bacteria that were identified to species. Black dots correspond to the bacteria that were identified to genus.

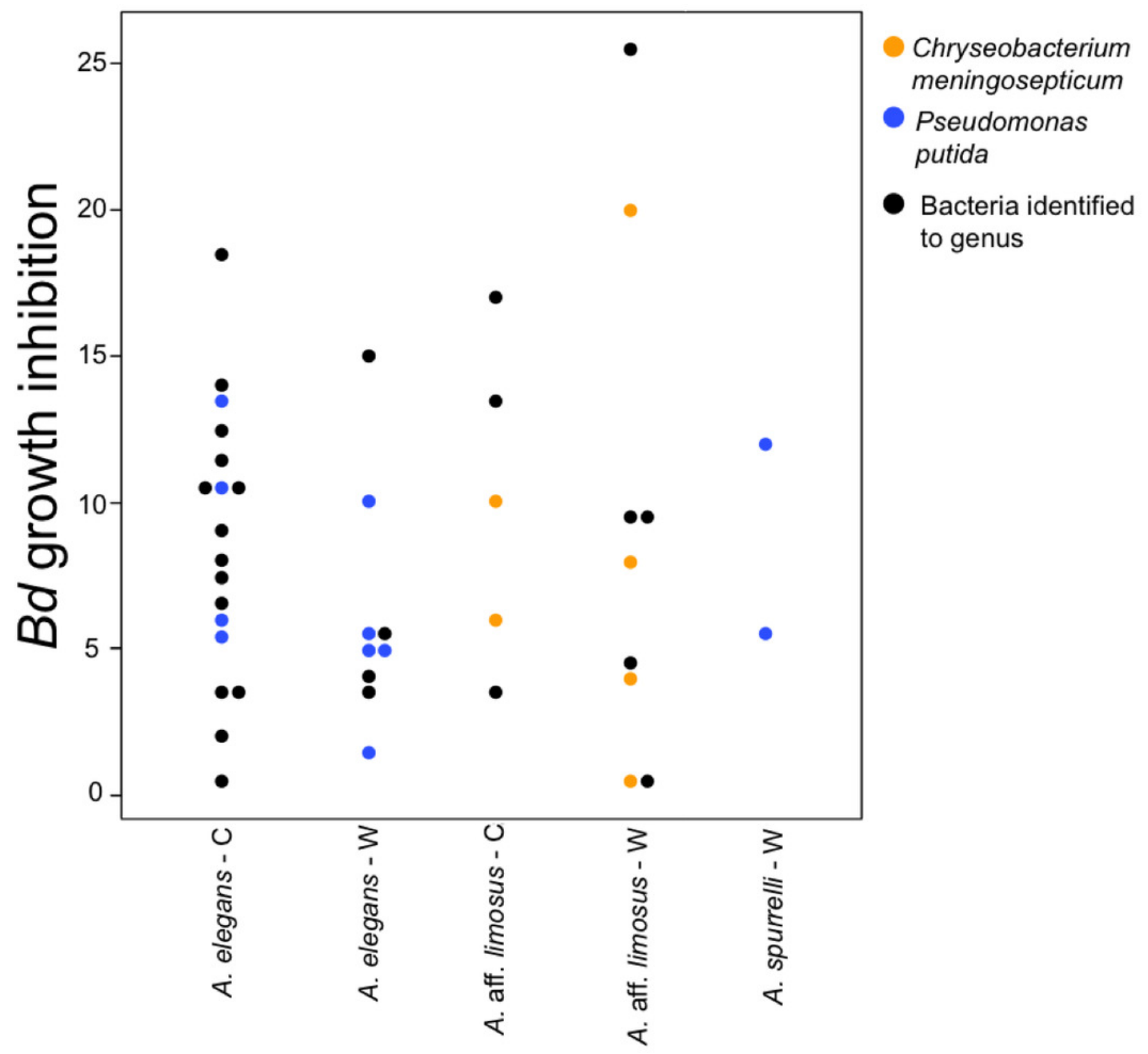




\section{Table $\mathbf{1}$ (on next page)}

Number of sampled individuals of each Atelopus species in wild and captive conditions

The table includes the localities in Colombia and Ecuador where Atelopus individuals were sampling, the year when individuals were collected and entered into an ex situ facility, as well as the year when bacterial samples were taken for the analysis of the culturable portion of the skin microbiota. 


\begin{tabular}{|c|c|c|c|c|c|c|c|}
\hline Species & $\begin{array}{c}\text { Site of } \\
\text { collection }\end{array}$ & Stage & $\begin{array}{l}\text { captive } \\
\text { ind. }\end{array}$ & $\begin{array}{c}\text { Year of } \\
\text { collection }\end{array}$ & $\begin{array}{c}\text { Date of } \\
\text { sampling } \\
\text { captive } \\
\text { individuals }\end{array}$ & $\begin{array}{l}\text { wild } \\
\text { ind. }\end{array}$ & $\begin{array}{c}\text { Date of } \\
\text { sampling } \\
\text { wild } \\
\text { individuals }\end{array}$ \\
\hline \multirow[b]{2}{*}{$\begin{array}{l}\text { Atelopus } \\
\text { elegans }\end{array}$} & \multirow[b]{2}{*}{$\begin{array}{l}\text { Esmeraldas, } \\
\text { Ecuador }\end{array}$} & Juvenile & 2 & $\begin{array}{l}1 \text { ind }-2009 \\
1 \text { ind }-2010\end{array}$ & 2012 & - & 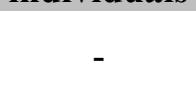 \\
\hline & & Adult & 8 & $\begin{array}{l}2 \text { ind }-2009 \\
3 \text { ind }-2010 \\
1 \text { ind }-2011 \\
2 \text { ind }-2012\end{array}$ & 2012 & 5 & 2012 \\
\hline \multirow{2}{*}{$\begin{array}{c}\text { Atelopus aff. } \\
\quad \text { limosus }\end{array}$} & \multirow{2}{*}{$\begin{array}{c}\text { Capurganá, } \\
\text { Colombia }\end{array}$} & Juvenile & 2 & $\begin{array}{c}\text { Born in } \\
\text { captivity in } \\
2011\end{array}$ & 2012 & - & - \\
\hline & & Adult & 5 & $\begin{array}{l}2 \text { ind }-2008 \\
3 \text { ind }-2009\end{array}$ & 2012 & 8 & 2009 \\
\hline $\begin{array}{l}\text { Atelopus } \\
\text { spurrelli }\end{array}$ & $\begin{array}{c}\text { Arusí, } \\
\text { Colombia }\end{array}$ & Adult & 4 & 2011 & 2012 & 5 & 2009 \\
\hline
\end{tabular}

1 


\section{Table 2 (on next page)}

Summary of the number of bacterial isolates recovered from three Atelopus species in captive and wild conditions

The number in parenthesis represents the percentage of isolates with anti-Bd properties. In the last column we detailed the number of bacterial species that exhibit some degree of anti-Bd activity. 


\begin{tabular}{llccc}
\multicolumn{1}{c}{ Species } & Condition & \# of isolates & $\begin{array}{c}\text { \# Anti-Bd } \\
\text { isolates }\end{array}$ & $\begin{array}{c}\text { \# Bacterial species } \\
\text { with anti- } \boldsymbol{B d} \text { activity }\end{array}$ \\
\hline \multirow{2}{*}{ Atelopus elegans } & Captive & 70 & $15(21 \%)$ & 7 from 3 genera \\
& Wild & 40 & $11(27 \%)$ & 9 from 7 genera \\
\hline \multirow{2}{*}{ Atelopus aff. limosus } & Captive & 62 & $29(47 \%)$ & 11 from 6 genera \\
& Wild & 77 & $20(26 \%)$ & 7 from 3 genera \\
\hline \multirow{2}{*}{ Atelopus spurrelli } & Captive & 21 & $6(28 \%)$ & 4 from 4 genera \\
& Wild & 21 & $6(28 \%)$ & 5 from 2 genera \\
\hline
\end{tabular}

1 


\section{Table 3 (on next page)}

Bacterial species isolated from the skin of Atelopus elegans, Atelopus aff. limosus and Atelopus spurrelli

$\mathrm{C}=$ Captive, $\mathrm{W}=$ Wild. The number in parenthesis represents the number of individuals sampled in each condition. Numbers in each cell represent the number of isolates for each bacterial species. Species that showed anti-Bd activity are marked with an asterisk (*). Bacteria highlighted in grey correspond to those present in captive and wild animals. 


\begin{tabular}{|c|c|c|c|c|c|c|c|}
\hline \multirow{2}{*}{ Family } & \multirow{2}{*}{ Bacterial Isolates } & \multicolumn{2}{|c|}{ A. elegans } & \multicolumn{2}{|c|}{ A. aff. limosus } & \multicolumn{2}{|c|}{ A. spurrelli } \\
\hline & & $\mathbf{C}(10)$ & $\mathbf{W}(5)$ & $\mathbf{C}(7)$ & $\mathbf{W}(8)$ & $\mathbf{C}(4)$ & $\mathbf{W}(5)$ \\
\hline Moraxellaceae & Acinetobacter baumannii & - & - & 1 & 3 & - & 2 \\
\hline Moraxellaceae & Acinetobacter bereziniae & - & - & 1 & - & - & - \\
\hline Moraxellaceae & Acinetobacter calcoaceticus & - & - & 1 & 2 & - & 1 \\
\hline Moraxellaceae & Acinetobacter genomosp. & - & - & - & 1 & - & - \\
\hline Moraxellaceae & Acinetobacter haemolyticus & - & - & - & - & - & $1 *$ \\
\hline Moraxellaceae & Acinetobacter gyllenbergii & - & - & - & $5 *$ & - & $1 *$ \\
\hline Moraxellaceae & Acinetobacter junii & - & - & - & 1 & - & - \\
\hline Moraxellaceae & Acinetobacter sp. & 2 & - & $3 *$ & $7 *$ & 2 & $2 *$ \\
\hline Moraxellaceae & Acinetobacter venetianus & - & - & - & 1 & - & - \\
\hline Aeromonadaceae & Aeromonas hydrophilia & 1 & - & - & - & - & - \\
\hline Aeromonadaceae & Aeromonas sp. & 1 & - & - & - & - & - \\
\hline Alcaligenaceae & Alcaligenes faecalis & - & - & $1 *$ & - & - & - \\
\hline Bacillaceae & Bacillus sp. & - & - & 1 & - & - & - \\
\hline Bacillaceae & Bacillus cereus & - & - & $2 *$ & - & - & - \\
\hline Sphingomonadaceae & Blastomonas natatoria & 4 & $3 *$ & - & - & - & - \\
\hline Brevibacteriaceae & Brevibacterium aureum & - & - & 1 & - & - & - \\
\hline Caulobacteraceae & Brevundimonas aurantiaca & 1 & 1 & - & - & - & - \\
\hline Caulobacteraceae & Caulobacter crescentus & - & 1 & - & - & - & - \\
\hline Caulobacteraceae & Caulobacter vibroides & - & 1 & - & - & - & - \\
\hline Flavobacteriaceae & Chryseobacterium indologenes & - & - & $2 *$ & - & - & - \\
\hline Flavobacteriaceae & Chryseobacterium meningosepticum & - & - & $1 *$ & $1 *$ & $2 *$ & 1 \\
\hline Flavobacteriaceae & Chryseobacterium sp. & - & - & $2 *$ & $5^{*}$ & - & - \\
\hline Enterobacteriaceae & Citrobacter freundii & - & $1 *$ & - & - & - & - \\
\hline Enterobacteriaceae & Citrobacter sp. & $1 *$ & - & - & - & - & - \\
\hline Comamonadaceae & Comamonas sp. & 3 & - & & 1 & 1 & 1 \\
\hline Comamonadaceae & Comamonas testosteroni & - & - & 2 & 1 & $1 *$ & 2 \\
\hline Oxalobacteraceae & Duganella sp. & - & 1 & - & - & - & - \\
\hline Dermacoccaceae & Dermacoccus sp. & - & - & 1 & - & - & - \\
\hline Enterobacteriaceae & Enterobacter asburiae & $1 *$ & - & - & - & - & - \\
\hline Enterobacteriaceae & Enterobacter sp. & 2 & 2 & - & - & - & - \\
\hline Enterobacteriaceae & Erwinia amylovora & - & 1 & - & - & - & - \\
\hline Streptomycetaceae & Kitasatospora phosalacinea & - & - & 1 & - & - & - \\
\hline Enterobacteriaceae & Klebsiella oxytoca & 1 & - & - & - & - & - \\
\hline Enterobacteriaceae & Klebsiella sp. & - & 1 & - & - & - & - \\
\hline Enterobacteriaceae & Kluyvera ascorbata & - & $1^{*}$ & - & - & - & - \\
\hline Microbacteriaceae & Leucobacter sp. & - & - & 1 & - & - & - \\
\hline Listeriaceae & Listeria sp. & - & - & 1 & - & - & - \\
\hline Xanthomonadaceae & Luteibacter rhizovicinus & - & $1 *$ & - & - & - & - \\
\hline Oxalobacteraceae & Massilia $\mathrm{sp}$ & 1 & - & - & - & - & - \\
\hline Microbacteriaceae & Microbacterium foliorum & 1 & - & - & - & - & - \\
\hline Microbacteriaceae & Microbacterium sp. & 1 & - & - & - & - & - \\
\hline Microbacteriaceae & Microbacterium testaceum & - & 1 & - & - & - & - \\
\hline Enterobacteriaceae & Morganella morganii & 1 & - & - & - & - & - \\
\hline Sphingomonadaceae & Novosphingobium aromaticivorans & 1 & - & - & - & - & - \\
\hline Sphingomonadaceae & Novosphingobium subterraneum & 2 & $3 *$ & - & - & - & - \\
\hline Enterobacteriaceae & Pantoea agglomerans & 1 & - & - & - & - & - \\
\hline Comamonadaceae & Pelomonas puraquae & 3 & - & - & - & - & - \\
\hline Pseudomonadaceae & Pseudomonas aeruginosa & $1 *$ & - & - & - & - & - \\
\hline
\end{tabular}


Pseudomonadaceae

Pseudomonadaceae

Pseudomonadaceae

Pseudomonadaceae

Pseudomonadaceae

Pseudomonadaceae

Pseudomonadaceae

Pseudomonadaceae

Pseudomonadaceae

Pseudomonadaceae

Pseudomonadaceae

Pseudomonadaceae

Pseudomonadaceae

Enterobacteriaceae

Rhizobiaceae

Sphingomonadaceae

Sphingomonadaceae

Sphingomonadaceae

Sphingomonadaceae

Staphylococcaceae

Xanthomonadaceae

Xanthomonadaceae

Nocardiaceae

Nocardiaceae

Enterobacteriaceae
Pseudomonas fulva

Pseudomonas geniculata

Pseudomonas montielli

Pseudomonas mosselii

Pseudomonas plecoglossicida

Pseudomonas putida

Pseudomonas saccharophilia

Pseudomonas sp.

Pseudomonas nitroreducens

Pseudomonas straminea

Pseudomonas tolaasii

Pseudomonas veronii

Pseudomonas vranovensis

Raoultella ornithinolytica

Rhizobium sp.

Sphingobium yanoikuyae

Shipngomonas paucimobilis

Sphingomonas sp.

Sphingopyxis sp.

Staphylococcus capitis

Stenotrophomonas maltophilia

Stenotrophomonas sp.

Tsukamurella sp.

Tsukamurella tyrosinosolvens

Yokenella regensburgei

\begin{tabular}{|cc|cc|cc}
1 & $\mathbf{1}^{*}$ & - & - & - & - \\
- & - & $\mathbf{1}^{*}$ & - & - & - \\
- & - & - & - & $\mathbf{1}^{*}$ & - \\
$1^{*}$ & - & $1^{*}$ & - & - & - \\
- & - & 1 & - & - & $\mathbf{1}^{*}$ \\
$\mathbf{2}^{*}$ & $\mathbf{1 *}$ & $\mathbf{2}^{*}$ & 1 & 1 & $\mathbf{2}^{*}$ \\
1 & - & - & - & - & - \\
$\mathbf{4}^{*}$ & $\mathbf{2 *}$ & 2 & 1 & 1 & 1 \\
- & - & - & - & - & 1 \\
- & - & - & - & - & 1 \\
- & - & - & 1 & - & 1 \\
- & - & - & $\mathbf{6}$ & - & - \\
$\mathbf{2}^{*}$ & - & - & - & - & - \\
- & 1 & - & - & - & - \\
1 & 1 & - & - & - & - \\
2 & - & - & - & - & - \\
1 & - & - & - & - & - \\
4 & 1 & - & - & - & - \\
4 & - & - & - & - & - \\
- & 1 & - & - & - & - \\
- & 1 & $\mathbf{4}^{*}$ & - & 1 & 1 \\
- & 1 & $\mathbf{2}^{*}$ & - & $\mathbf{1 *}$ & - \\
1 & - & - & - & - & - \\
1 & - & - & - & - & - \\
- & 1 & - & - & - & - \\
\hline & & & & &
\end{tabular}

1 